УДК 821.161.2-3.09

DOI https://doi.org/10.26661/2414-9594-2020-2-23

\title{
ДО ПИТАННЯ ПРО ОСОБЛИВОСТІ ЖАНРОТВОРЕННЯ В ЛІТЕРАТУРІ ДОБИ КИЇВСЬКОЇ РУСІ
}

\author{
Білоус Б. П. \\ кандидат філологічних наук, дочент, \\ дочент кафедри теоретичної та прикладної лінгвістики \\ Державний університет «Житомирська політехніка» \\ вул. Чуднівська, 103, Житомир, Украӥна \\ orcid.org/0000-0001-6108-5827 \\ bilousbogdan07@gmail.com
}

\author{
Ключові слова: жанр, \\ жанротворення, \\ середньовічна література, \\ символіка, алегорія, \\ Київька Русь.
}

\begin{abstract}
Мета і завдання статті - запропонувати новий підхід до принципів жанротворення в українській літературі доби Київської Русі. Суть такого підходу полягає у тому, щоб розглядати давні жанри як спосіб висловлювання (за Ф. Сосюром). Літературні жанри періоду Київської Русі раніше переважно поділялися на церковні і світські, первинні i синкретичні. Ми пропонуємо застосувати до диференціації жанрів принцип, який спирається на характер висловлювання. За висловом писемним виділяємо такі жанри, як: азбуковник, літопис (хронограф, хроніка), епістолія, послання, «книга», «чтеніє», «описаніє», афоризм. За висловом усним такі як: бесіда, діалог, молитва, повість, повчання, похвала, «слово», сказання, «толкованіє». Ще один принцип диференціації жанрів - віднесеність їх до предмета зображення, який і визначає його специфіку: житіє, видіння, «історія», ходіння, чудо. Часом на характер жанру вказує назва твору, яка пояснює або предмет зображення, або його ідейне спрямування, або наративну форму; серед тих назв $є$ такі, що запозичені зі Святого Письма, що виражають метафоричний смисл середньовічної символіки та алегоризму. Фольклорні жанри ми не відносимо до жанрів літературних, оскільки вони мають інший культурний код. Фольклорні жанри функціонували паралельно до книжності, іноді проникаючи у сферу літературну, додаючи до писемних творів свої семантично-художні елементи. Естетика, онтологія, прагматика, типологія давньоукраїнських жанрів історично зумовлені, покликані до життя певними суспільнополітичними та естетичними чинниками та потребами, тісно пов'язані i3 характером та виявом естетичних цінностей середньовічної епохи, визначаються ними і становлять певну систему сприймання і відтворення світу, а отже, і систему жанрів, які забезпечували духовне, культурне життя давньої пори.
\end{abstract}




\title{
TO THE QUESTION OF FEATURES IN LITERATURE OF KIEV RUS PERIOD
}

\author{
Bilous B. P. \\ Candidate of Philological Sciences, Associate Professor, \\ Associate Professor at the Department of Theoretical and Applied Linguistics \\ Zhytomyr Polytechnic State University \\ Chudnivska str., 103, Zhytomyr, Ukraine \\ orcid.org/0000-0001-6108-5827 \\ bilousbogdan07@gmail.com
}

Key words: genre, genre creation, medieval literature, symbolics, allegory, Kyiv Rus.
Aim and task of the article - to offer the new going near principles of genre creativity in Ukrainian literature of Kyiv Rus. Essence of such approach consists in that, to examine old genres as method of expression (F. Sosyur). The literary genres of period of Kyiv Rus before were mainly divided into church and society, primary and syncretism. We suggest to apply to differentiation of genres principle that leans against character of expression. After expression writing distinguish such genres: azbukovnik, chronicle (chronograph, chronicle), epistolia, message, "book", "chtenie", "opusanie", aphorism. After expression verbal: conversation, dialogue, prayer, story, discipling, praise, "word", conversation. Another principle of differentiation of genres - attribute them to the article of image, that determines his specific: life, vision, "history", circulation, miracle. Sometimes the name of work, that explains or the article of image, specifies on character of genre, or him ideological aspiration, or narrative form; among those names there are such that is adopted from Holy Scriptures, that express metaphorical sense of medieval symbolics and allegory. Folklore genres we do not attribute to the genres literary, as they have other cultural code. Folklore genres functioned in parallel to the book, sometimes getting to the sphere literary, adding the semantically-artistic elements to writing works. Aesthetics, ontology, pragmatic, typology of old Ukrainian genres, is historically predefined, called to living by certain social and political and aesthetic factors and necessities, closely constrained with character and display of aesthetic values of medieval epoch, determined by them and present the certain system of perception and recreation of the world, and consequently and system of genres that provided spiritual, cultural life of old pore.
Постановка проблеми. У наукових концепціях XIX-XX ст. щодо літературних жанрів періоду Київської Русі найчастіше застосовувався принцип розподілу їх на церковні і світські, первинні й синкретичні. На наш погляд, диференціація «церковні/світські» більшою мірою відображає їх функційне призначення, виходить 3 ідеологічних передумов (такий підхід особливо часто використовувався в епоху «войовничого атеїзму», коли «церковне» засуджувалося, а елементи «світського» всіляко вишукувалися й акцентувалися як «прогресивне» явище). Так, частина давніх жанрів обслуговувала релігійний культ, церковний обряд, і в цьому була їх специфіка. Суто світських жанрів тоді практично не було, навіть літописи були пронизані державно-християнською доктриною, а такі пам'ятки, як «Слово про Ігорів похід», також виражали релігійні погляди і помисли - язичницькі.
Щодо «первинних/синкретичних» жанрів, то і такий поділ досить умовний і далеко не відображає параметри жанрового діапазону літератури у період первинного нагромадження текстів. Принцип такого підходу очевидний - від простого до складного у жанротворчості. Але ж літературна ситуація Київської Русі полягає у тому, що засвоювалися «готові» жанри візантійсько-болгарського зразка, їх навряд чи можна вважати первинними, як і не можна заперечувати процесу жанрової градації або появи таких творів, у яких помітні прикмети різноманітних тогочасних жанрів. Очевидно, тут необхідний інший підхід, який би спирався на характер вислову.

У період зародження вітчизняної медієвістики (40-60-і pp. ХIX ст.) звернення до давньої літератури визначалося ранньонародницькою та романтичною настановою, тому увагу привертали лише окремі літературні явища, а жанрова специфіка 
практично не аналізувалася, не було спроб реконструювати систему давньоукраїнських жанрів. Праці М. Максимовича, І. Вагилевича, Я. Головацького, М. Костомарова, П. Куліша були тільки першими спробами осмислити літературну спадщину минулого i дати характеристику деяким писемним пам'яткам давнини.

Під кінець XIX ст. помітно і принципово змінюються методологічні засади у висвітленні історії української літератури, зокрема її найдавнішого періоду. О. Огоновський своєю «Історією літератури руської» подає лише своєрідну інвентаризацію старовинних творів, а не укладає їх у певну жанрову систему; його жанрова модель ще неповна, не досить оброблена. Концепція жанротворення у висвітленні I. Франка спирається на широкий діапазон літературного розвою в XIXIII ст. і доводить творчу спроможність давнього письменства. Послуговуючись переважно культурно-історичним методом, учений зумів подати значно ширшу картину літературного життя Русі, заповнив іiі багатьма «творчими одиницями», що дало змогу вперше більш-менш повно окреслити жанровий склад літератури цього часу. Концепція М. Грушевського спиралася на пізнє народництво та історико-філологічний підхід до давніх пам'яток. Внаслідок цього в його «Історії української літератури» було запропоновано деталізовану реконструкцію системи давньоукраїнських жанрів як оригінального явища, що було зумовлене низкою історичних та естетико-культурних обставин. Дослідник дав характеристику складної природи колоритних жанрових утворень на староруському грунті. 3 концепцією М. Грушевського багато в чому перегукується методологія дослідження давнього письменства М. Возняка, котрий висвітлив жанрове розмаїття Київської Русі з погляду самобутності, суспільно-політичної інтегрованості, естетичної вартості пам'яток. С. Єфремов у вивченні давньої літератури проводив передусім соціологічний принцип, подавав «історію ідей», тому й не відтворив розгорнутої жанрової картини на початковому етапі розвитку літератури, вважаючи, що більшість творів була запозичена і призначалися вони для обслуговування церковних потреб. Загальнолітературна концепція С. Єфремова не надавала особливого значення тому всьому масивові давніх творів, які постали на ідейному грунті християнства, а вихоплювала лише окремі 3 них, що мали «народний» колорит і спрямування.

Синтетичні праці, дослідження з медієвістики, публікація літературних текстів у XX ст. не тільки значно доповнили наукові уявлення про становлення давніх жанрів в українському письменстві, а й запропонували низку концепцій у прочитанні і тлумаченні літературної спадщини минулого. Її вивчення велося кількома шляхами: 1) осмислення давніх жанрів у контексті формування і розвитку стилів у давній літературі (М. Гнатишак, Д. Чижевський); 2) з'ясування жанрової системи в основному крізь призму соціологічних орієнтирів, котрі вбачалися у давніх творах періоду Київської Русі («Історії» української літератури); 3) співвіднесення давніх жанрів і стилів із загальноєвропейськими художніми явищами, уведення їх у світовий літературний контекст (В. Яременко, П. Білоус, Ю. Ісіченко, О. Пахльовська, О. Сліпушко).

Мета і завдання статті - запропонувати новий підхід до визначення принципів жанротворення в українській літературі доби Київської Русі. Суть такого підходу полягає в тому, щоб розглядати давні жанри як спосіб висловлювання.

Виклад основного матеріалу. Будь-який літературний твір - це мовлення, основною одиницею якого є висловлювання. Ф. де Сосюр вважав, що висловлювання - це «індивідуальний акт волі і розуму, де слід розрізняти: 1) комбінації, у яких мовець застосовує мовний код, аби висловити власну думку; 2) психофізичний механізм, який дозволяє йому унаявнити ці комбінації» [6, с. 26]. Жанрова форма висловлювання конкретизує спосіб і спрямованість висловлювання. Окрім того, вона забезпечує цілісність висловлювання, про що вів мову М. Бахтін: «Ця завершена цілісність висловлювання, яка забезпечує можливість відповіді (або відносного розуміння), визначається трьома моментами (чи факторами), нерозривно пов'язаними в органічному цілому висловлювання: 1) предметно-смисловою вичерпністю; 2) мовним замислом або мовною волею мовця; 3) типовими композиційно-жанровими формами завершення» [2, с. 269].

Жанр постає як організована певним чином словесна форма, характер якої залежить від способу вислову. У межах знакових систем, які стосуються словесності, є два такі способи: вислів усний і вислів писемний. I хоча література - це виключно писемна форма словесної творчості, проте за часів Київської Русі ще відчувається вплив форм усної словесності на літературу, що виявляє себе як у жанрово-стильових особливостях творів, так і в їхніх назвах. Отже, пропонується перший рівень диференціації жанрів, пов'язаний із способом висловлювання.

За висловом писемним можемо назвати такі жанри:

- азбуковник («Азбучна молитва», віршовий твір, акростих, що відтворює слов'янську азбуку);

- літопис, хронограф, хроніка (один із магістральних жанрів у давній літературі);

- епістолія («Епістолія Ісуса Христа про неділю» - перекладний апокриф, але у формі письмового послання); 
- послання (визначальною тут є не стільки форма, скільки зміст та адресованість тексту, наприклад, послання Клима Смолятича);

- книга (жанрова домінанта - форма книги, тобто текст, укладений як книга, наприклад, «Книга Паломник» Добрині Ядрейковича);

- «чтеніє» - твори, що призначені для читання («Чтеніє о житії і о погублєнії блаженних страстотерпців Бориса та Гліба» Нестора);

- «описаніє» («начертаніє») - «Описаніє подвигів Георгія Побідоносця»;

- афоризми («Пчела», «Мудрість Меандра», «Перенесіс» Сфрема Сірина).

За висловом усним:

- бесіда («Бесіда про святині Царгорода», «Бесіди на Свангеліє», «Бесіда трьох святителів»);

- «двоєсловіє» (діалог) - «Вопрошаніє Кирикове», «Вопроси Варфоломієві до Богородиці»);

- молитва (літературний варіант - «Моленіє» Данила Заточника);

- nовість (під такою назвою значиться чимало давніх творів, проте їхньою жанровою домінантою є манера вислову - розповідь);

- повчання (здебільшого як усне вираження настанов - «Повчання про шкоду пияцтва» Мойсея, повчання Клима Смолятича, Георгія Зарубського, Луки Жидяти);

- похвала (очевидно, первісний варіант жанру - усне проголошення похвали - «Похвальне слово Ользі», «Похвала князю Ростиславу Мстиславовичу»);

- «речь» (у значенні «слово»; назва із таким значенням трапляється досить часто як у перекладних, так і в оригінальних творах);

- сказання («Сказання про Бориса та Гліба», «Сказання про вбивство в Орді князя Михайла Чернігівського та його боярина Федора», «Сказання про чорноризький чин» Кирила Турівського та ін.);

- «толкованіє» («Толкованіє на послання апостола Павла», «Толкованіє на Апокаліпсис», «Толкованія на Псалтир» тощо).

Деякі з названих жанрів можуть бути віднесені як до однієї, так і до іншої групи - наприклад, повчання, похвала, «Толкованіє», діалог, оскільки за способом вислову вони однаковою мірою можуть реалізуватися (або взаємопереходити) і в усному, і в письмовому варіанті.

Але для давньоукраїнської літератури визначення жанрів за способом вислову не вичерпує різноманітності жанрових форм, тому тут варто застосувати ще один принцип - віднесеності їх до предмета зображення, який ніби «програмує» специфіку жанру:

- житіє (перекладні й оригінальні житія); жанрові варіанти (різновиди) - мартирії («Мученіє Варвари», «Мученіє Дмитрія Солунського, «Мученіє Микити», «Мученіє Федора Стратилата» та ін.; патерики (Азбучно-Срусалимський,
Сгипетський, Римський, Синайський, Скитський, Києво-Печерський); пам 'ять («Пам'ять і похвала князю Володимиру»); «страсть».

- видіння («позорище») - «Видіння Ісайї»;

- «історія» («Історія Іудейської війни»);

- ходіння (Житіє і хоженіє Данила, Руської землі ігумена», «Ходіння Агапія в рай», «Ходіння Богородиці по муках»);

- чудо («Чудо Георгія про змія», розповіді про чудеса, що мають самостійне наративне значення (із «Повісті минулих літ», «Повісті про Варлаама та Іосафа», «Сказання про Свстафія Плакиду», «Повісті про Акира Премудрого», «Девгенієвих діянь», «Фізіолога», «Слова про рахманів», «Києво-Печерського патерика» тощо).

Назва жанру у давньоукраїнській літературі має велике значення. Часто вона є своєрідним ключем розуміння специфіки жанру, його призначення та мистецької орієнтації. У письменстві Київської Русі трапляються не лише жанрові мононазви, а й маємо чимало прикладів «подвійних» назв, тобто до загальної назви входить декілька компонентів, якими визначається або предмет, або спрямування, або форма вислову того чи іншого твору. Наприклад: «Сказання і бесіда премудра», «Повість і писаніє», «Житіє і хоженіє», «Пам'ять і похвала», «Слово і сказання», «Поклон і благословіння», «Повість про житіє», «Житіє і діяння», «Житіє і чудеса», «Посланіє і істолкованіє» тощо. Таке називання творів дає підставу вести мову про прагнення автора (авторів) скерувати увагу читача на певний тип рецепції пропонованого твору, задекларувати не так його жанр, як предмети зображення. У таких творах можна помітити синкретизм оповідних форм, що засвідчує нерозвинутість, нерозгалуженість жанрів і стилів того часу.

Серед розмаїття пам' ятокперіоду Київської Русі зринають назви творів, жанр яких можна визначити як пряме запозичення зі Святого Письма: «глава», «завіт», «діяння», «одкровення», «книга» («Заповіти дванадцяти апостолів», «Одкровення Варуха», «Одкровення Мефодія Патарського», «Книга Паломник» та ін.). Схоже, що автори «підганяли» назву під зміст або навпаки, і так з'являлися літературні відгалуження від священного тексту; назва підкреслювала і генетичний зв'язок 3 ним, і значущість новотвору.

У ті часи письменники і переписувачі текстів охоче практикували метафоричні назви в дусі середньовічної символіки та алегоризму: «вертоград», «вінець», «пчела», «ізмарагд», «цвітослов», «брашно духовне», «златоструй», «златослов», «златоуст», «златая цепь», «торжественник» тощо. Немає потреби відносити такі твори (серед них переважають збірники, складені з різних за змістом і стилем текстів) до певних жанрів. Немає потреби й кваліфікувати їх як жанрово синкретичні літературні явища. У межах збірника 
можна виділяти певні жанрові форми або розглядати принципи його укладання. Назва збірника здебільшого не була жанровим атрибутом, а скоріше його образним визначенням.

Проблематичним видається твердження деяких дослідників про те, що жанрова картина літератури періоду Київської Русі доповнювалася фольклорними жанрами, зокрема ліричними й драматичними $[1 ; 5 ; 4]$. Слушно було б вести мову про елементи фольклору в давній літературі, проникнення яких у текстуру візантійських традицій стало неминучим на києворуському грунті [3]. Фольклорні жанри функціонували паралельно до книжності, яка не мала і не могла мати «всенародного» характеру, бо літературні твори оберталися здебільшого у вузькому колі тодішньої світської та церковної інтелігенції. У Київській Русі домінувала тенденція окремішності в побутуванні літературних і фольклорних жанрів, i так тривало не одне століття, аж поки візантійський тип літературної творчості не був витіснений фольклорним та новоєвропейським.

Досі говорилося переважно про типологію (класифікацію, систематизацію) давньоукраїнських жанрів періоду їх становлення. Вона заснована на виявленні та абстрагуванні подібних прикмет, характерних для певної групи художніх творів. Ті прикмети стосуються як їхнього змісту, так і форми, а також відображають динаміку ї становлення та історичної еволюції.

Варто сказати i про онтологію давньоукраїнських жанрів. Як уже зазначалося, вони історично зумовлені, покликані до життя певними суспільно-політичними та естетичними чинниками і потребами. Водночас це означає, що кожен давній жанр увібрав у себе як історичний досвід запозичених форм, так і набутий досвід києворуського функціонування. У ньому знайшли своє відображення прикмети часу, виявившись у тематиці, художній ідеології, телеології (перспективі) тексту, у принципах моделювання картини світу. «У жанрах, - підкреслював М. Бахтін, - протягом століть їх життя нагромаджуються форми бачення й осмислення певних сторін світу» [2, с. 264].

Естетика давньоукраїнського жанру тісно пов'язана із загальним тлом естетичних цінностей епохи, визначається ними та являє собою певну систему сприймання і відчуття світу; кожен жанр - взагалі складна система засобів і прийомів «оволодіння дійсністю», своєрідний тип художнього мислення в межах свідомо прийнятих естетичних координат.

Прагматика давніх жанрів залежала не тільки від функційної прив'язаності до сфери обслуговування церковного життя, релігійного культу, а й була спрямована на задоволення естетичних, пізнавальних, виховних потреб читача. Ефективність жанру, його корисність у тодішньому культурному житті прямо пов'язана 3 рівнем художньої майстерності, 3 оволодінням письменником законами жанру. Тому творче «обживання» жанру у ті часи стимулювало вдосконалення літературного письма митця, а вільне володіння формою сприяло досягненню у літературі помітних здобутків.

Висновки. Бурхливий процес жанротворення в період Київської Русі великою мірою визначив шляхи розвитку жанрової системи давньої української літератури. Жанровий склад письменства найдавнішого часу характеризується первинним нагромадженням текстів, їхнім структуруванням за соціальною значущістю та естетичними пріоритетами. Втрата якоїсь кількості писемних пам'яток, втрата протографів (маємо переважно лише списки пізнішого часу) призвела до зрозумілих труднощів у реконструкції системи жанрів києворуського періоду, проте й наявний матеріал дає змогу простежити, окреслити визначальні тенденції становлення жанрової системи давньої української літератури.

\section{ЛІТЕРАТУРА}

1. Адрианова-Перетц В.П. Древнерусская литература и фольклор. Ленинград : Наука, 1974. 171 с.

2. Бахтин М.М. Эстетика словесного творчества. Изд. 2-е. Москва : Искусство, 1986. 445 с.

3. Білоус П.В. Давньоукраїнська література і фольклор: проблема художнього коду. Слово $і$ час. 2002. № 12. C. 29-35.

4. Возняк М.С. Історія української літератури: У 2 кн. Кн. 1. Львів, 1992. 696 с.

5. Лихачев Д.С. Поэтика древнерусской литературы. Москва : Наука, 1979. 360 с.

6. Фердінан де Сосюр. Курс загальної лінгвістики. Київ : Основи, 1998. 324 с.

\section{REFERENCES}

1. Adrianova-Perets, V.P. (1974). Drevneruska literature i folklore [Ancient literature and folklore]. Leningrad: Nauka, P. 171.

2. Bahtin, M.M. (1986). Etuka slovesnogo tvorchestva [Aesthetics of verbal creativity]. Vol. 2. Moskva : Art. P. 445.

3. Bilous, P.V. (2002). Davnyoruska literatura I folklor: problema hydozhnyogo kodu [Ancient Rus literature and folklore: problem of main code]. Slovo I Chas. No. 12. P. 29-35.

4. Voznyak, M.S. (1992). Istoria ykrainskoyi literatyru: u 2 kn. [History of Ukrainian literature: in 2 Vol]. Vol. 2. P. 696.

5. Lihachov, D.S. (1979). Poetika drevnerusskoi literatyru [Poetics of old Rus literature]. Nayka. P. 360.

6. Ferdinand de Sosyur (1998). Kurs zagalnoyi lingvistuku [General linguistics course]. Osnovu. P. 324. 